\title{
Development of Online Portfolio Assessments (Apoline) to Measure Attitude and Concept Understanding of Students In Introduction to The Philosophy Course In PGSD Department of FIP Undiksha
}

\author{
${ }^{1}$ Desak Putu Parmiti, ${ }^{2}$ I Nyoman Laba Jayanta, ${ }^{3}$ I Ketut Dibia \\ $\left\{\right.$ 1'dp-parmiti@undiksha.ac.id, ${ }^{2}$ laba.jayanta@undiksha.ac.id, ${ }^{3}$ dibia@undiksha.ac.id $\}$ \\ ${ }^{1,2,3}$ Universitas Pendidikan Ganesha, Indonesia
}

\begin{abstract}
The aim of this study is to develop an online portfolio assessment (Apoline) for the Introduction to Philosophy course in PGSD Department of Undiksha. Apoline was also developed to improve the mastery of student concepts in the Introduction to Philosophy courses. The type used in this research is development research using a 4-D model consisting of: define, design, develop and disseminate. Data was collected using the questionnaire method and tests. The questionnaires were analyzed using quantitative descriptive techniques whereas, the test were analyzed using t-test statistics. The validity of the design aspects obtained a very good category and the assessment aspects obtained a very good category. Students also responded that Aponline was in the good category. After being applied, it turned out that Apoline is able to improve the discipline, honesty and curiosity of students. Likewise the mastery knowledge of students increases which is proved by t test.
\end{abstract}

Keywords: assessment, online portfolio, attitude, mastery of concepts

\section{Introduction}

In the 21st century the problem of the character is often became the highlight of the community. The highlight is on various aspects of life, which are contained in various writings in print media, interviews, dialogue, and the title of speech in electronic media. Mustari (2012) stated that there are two character development issues that are being faced, namely macro and micro issues. Macro issues included: (1) the disorientation and inadequacy of Pancasila values as the ideology of the nation, (2) the limitations of the integrated policy of Pancasila values, (3) the shifting of ethical values in the life of nation and state, (4) the waning of the awareness of national cultural values, (5) the threat of national disintegration, and (6) the weakening of national independence. Micro problems included: (1) brawling amongst students, (2) drug abuse, (2) discipline violations, (3) lack of awareness of cleanliness, (4) deteriorating culture of queuing, and so on.

The awareness to reinvest national character values has been echoed by various parties, including universities, namely Undiksha which has a vision of becoming a superior university based on the philosophy of Tri Hita Karana in Asia in 2045. Emphasizing on the Tri Hita Karana concept on that vision is a form to shape character of graduates who are virtuous. Undiksha is obliged to develop student character as a continuation of character education from previous levels of education. As is known that the process of developing character values is a long process 
from the beginning of students entering to completion of an educational unit. Besides having a superior character, Undiksha students are also required to have knowledge and skills in their fields. Mastery of knowledge and skills optimally is the provision of students when they will enter the real working situation.

Character values for each individual student often show through everyday attitudes both on campus and off campus. Aspects of attitude, mastery of knowledge, and skills are competency abstractions of a student or learner. Learners can be said to be competent if the three things can be relied upon in facing the demands and challenges in life. Learners are not enough to only have well-established knowledge and skills but must also have a good attitude. These three aspects constitute an integral whole that students should have as the next generation. The formation of a virtuous attitude, mastery of knowledge, and skills in each learner is the hope of each educator and educational goals. However, this expectation has not been fully realized, especially for the students of PGSD department FIP Undiksha, especially those who took Introduction to Philosophy course in the previous semester. Some students' attitudes have not shown the expected ideal. In terms of timeliness, there are still students who come late in class, undisciplined, and do not submit the assignments on time. The hardest challenge that must be fostered is the value of honesty. There are still a number of students plagiarizing the writings of people, whether belonging to classmates, sources from the internet, or belonging to experts without including the source. In addition, the mastery of the concepts by students is also not optimal. There are important concepts which do not well mastered so that in making the final assignment, mistakes often occur as in the case of making part of the discussion in a paper. Students still often do some mistakes in making content that tends to repeat the theory and minimal exposure based on the results of their own understanding and elaboration. This shows that mastery of concepts and skills of students is still far from what is expected and needed.

Having a good attitude, knowledge, and skills is the prominent provision of PGSD students as future elementary school lecturer candidates. Mastery of good competencies, attitudes, knowledge, and skills cannot be separated from what the learning process carried out. The learning process will run well if the learning system components can be optimally functioned. The components of the learning system are goals, materials, methods, media, assessment, students, and lecturers. One component that contributes to the learning process is assessment. Assessment is one of the main components in the learning process which is a strategic part to determine the accuracy of learning outcomes. The objectives of the assessment are to find out the level of achievement of the learning objectives and see the effectiveness of the learning process.

Given the above problems, one of the ways to overcome the students' achievement of the ideal attitude and mastery of the concept that is not yet optimal is by applying authentic assessment or assessment methods. Authentic assessment is a type of assessment that directly reveals or measures the process and results of students' learning and ensures that what is being assessed is truly the real competence of an individual. Authentic assessment is one way that can be used to control and direct all students' learning activities such as attitudes, knowledge and skills. One relevant type of authentic assessment applied is portfolio assessment. Portfolio assessment is an assessment that consists of a collection of students' work that is structured systematically that shows and proves learning efforts, learning outcomes, learning processes and progress made by the learners in a certain period of time (Zainul, 2001). The reason for choosing portfolio assessment is to pay attention to several things, namely: 1) the portfolio is able to assess the learning process over time, 2) a more realistic portfolio of written test assessments, 3) allows educators, learners, and parents to evaluate learners' strengths and weaknesses , 4) provide opportunities for learners to demonstrate their strength or ability, 5) 
encourage learners to develop the abilities needed to become independent learners, 6) encourage learners to think in creative ways to share what they learn (Asturias et al in Birgin \& Tray, 2007).

Considering the development of information and communication technology (ICT), the principle of effectiveness and efficiency should also be considered so that in conducting the assessment, it is appropriate to use ICT. For this reason, portfolio assessments will be developed online so it can be accessed through a website. In this study, online portfolio assessments abbreviated as "Apoline (Asesmen Portofolio Online)" will be more accessible to students compared to manual or traditional portfolios. Apoline can be accessed by students wherever they are. The tasks of paper, writing, photographs, videos, audio recordings, animations, images, various types of typography, and hypertext can be uploaded practically by students and it is also easier to create a more attractive portfolios.

Apoline is used as an effort to overcome the weaknesses of using traditional assessments that are offline. The assessment used so far in lectures is written tests both objective tests and essay tests. The weakness of this test, especially the objective test, is that it does not thoroughly measure students' competency and tend to only measure cognitive abilities. The objective tests that have been used so far are also not ICT-based so the feedback cannot be immediately displayed and randomization is difficult to do. Some of these weaknesses can be overcame by Apoline. Apoline provides an opportunity for students to proceed to complete every work as optimally as possible. In the Apoline, a deadline system for the completion of each work will be designed starting from preparation, manufacture and collection. Subsequently uploaded works can immediately be corrected by the lecturer and the results of the correction can also be immediately displayed on the Apoline system. Besides that, it also can be used to measure knowledge, skills, including attitudes.

In implementing Apoline, each student will have a different username and password. Students' activities will all be recorded on the Apoline system, both their attitude and knowledge. On the aspect of attitude, starting from the attitude of discipline will be recorded through the timeliness of uploading the work to the system, if they submit it later than the deadline then students cannot upload their work. The aspect of honesty will be assessed from the suitability of the tasks that are scientific rules, detection with a plagiarism system so that students are expected to make assignments with the correct ethics of quotation. Curiosity is measured through a discussion forum at Apoline and students are required to give their opinions and views on the topics discussed by the lecturer. In addition to measuring attitudes, Apoline is expected to further enhance the mastery of student concepts through the making of their best work. Understanding a concept will be given through giving problems. From these problems students are expected to be able to identify the correct and wrong concepts. Apoline also provides opportunities for students to carry out self-assessments on the extent of their attitudes and knowledge.

Apoline development is also inseparable from several research results. Garrett (2011) conducted a research by developing an e-portfolio software that finds that e-portfolios can encourage students to learn from each other and feel about their own learning process. The results of Khales (2016) study showed that e-portfolios were able to improve mastery skills. In addition Aygun and Aydin's research (2016) showed that e-portfolios are able to increase writing motivation, writing skills, and reflective learning. The results of this study strongly support the use of Apoline for the Introduction to Philosophy course in PGSD Department of FIP Undiksha which focuses more on mastering competencies in writing and reviewing Philosophy Education. Thus the development of Apoline is very necessary in the Introduction to Philosophy in PGSD Department of FIP Undiksha. The formulation of the objectives of this 
study are (1) describing the stages of online portfolio development based on the 4D development model, (2) describing the results of validation of online portfolio assessment from experts and student trials, (3) describe the effectiveness of online portfolio assessment in measuring attitudes and student's concepts mastery in Introduction to Philosophy courses.

\section{Method}

This type of research is development research. The development model used is a 4-D model consisting of Define, Design, Develop, and Dissemination stages. In this study respondents are involved in accordance with the testing phase, namely, the stage of expert testing, individual testing, small group testing, and field testing. When the expert test was used two experts namely media experts and assessment experts. At the time of individual testing, 3 students were selected based on population characteristics, namely gender differences and heterogeneous abilities. In the small group test stage, 12 students were chosen with the characteristics of the respondents the same as when testing individuals. At the stage when the field test is done, 30 students were involved at once to find out the effectiveness of Apoline. At the time of the field test is done, One Group Pretest Posttest Design research design is used. At the pretest and posttest, the instrument was in the form of a descriptive test. In addition, at the time of the field trial measured the attitudes of students using the observation sheet. Data is collected using methods and instruments that are adapted to the stages of product development. The following is a summary of the methods and instruments for data collection.

Table 3.1 Methods and Data Collection Instruments

\begin{tabular}{|r|l|l|l|l|l|}
\hline No & \multicolumn{1}{|c|}{ Method } & \multicolumn{1}{|c|}{ Instrument } & \multicolumn{1}{|c|}{ Type Of Data } & \multicolumn{1}{c|}{$\begin{array}{c}\text { Data } \\
\text { Source }\end{array}$} & \multicolumn{1}{|c|}{ Stage } \\
\hline 1. & Observation & Observation sheet & $\begin{array}{l}\text { Students' learning } \\
\text { outcome }\end{array}$ & Students & Define \\
\hline 2. & Questionnaire & Questionnaire & Expert response & Expert & Develop \\
\hline 3. & Questionnaire & Questionnaire & Students' response & Students & Develop \\
\hline 4. & Non-test & Observation sheet & Attitude & Students & Disseminate \\
\hline 5. & Test & Description Test & Knowledge & Students & Disseminate \\
\hline
\end{tabular}

The data that has been collected using questionnaires and subsequent observation sheets were analyzed descriptively. While data obtained through subsequent tests will be analyzed using inferential t-test statistics to determine the effectiveness of Apoline in measuring mastery of concepts by students. The t-test will be carried out using SPSS software. Instruments available at https://osf.io/7zc53/

\section{Results and Discussion}

The results of this study are the electronic systems that are used for assessment in the Introduction to Philosophy course. The developed system was named the Online Portfolio Assessment (Apoline) which was made by a systematic process using the 4D model. This below is the display of Apoline. 
Based on the design expert's assessment, apoline scores 92.50 which fall into very good category while experts gets a score of 90.00 which is in the very good category. Students also provide responses to the developed Apoline which scores 88 which fall into good category. After being through expert tests and limited student trials, Apoline is then implemented in learning to determine its effectiveness in improving student attitudes and learning outcomes. The

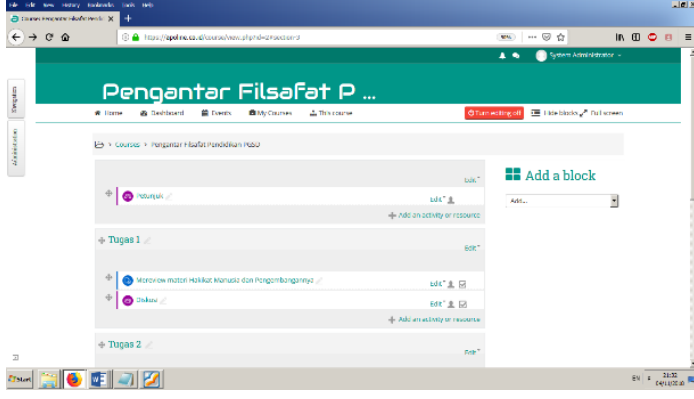

Figure 4.1 Interface of Apoline 1 attitude measured is discipline, honesty, and student curiosity. To find out the occurrence of an increase in attitude was carried out preliminary observations and final observations, while the knowledge aspect was known through the pretest and posttest. The results of the initial observations and final observations of student attitudes can be presented as follows.

Table 4.1 Results of Students' Attitude Observations

\begin{tabular}{|l|l|l|l|}
\hline No & Behavior & Initial Score & Final Score \\
\hline 1 & Discipline & 72 & 80 \\
\hline 2 & Honesty & 70 & 75 \\
\hline 3 & Curiosity & 75 & 87 \\
\hline
\end{tabular}

Based on table 4.1, there appears to be an increase in discipline, honesty and curiosity scores. This indicates that Apoline has an impact in increasing students' attitudes. Furthermore, to find out the increasing in knowledge was carried out by doing pretest and posttest, the results of it are presented in table 4.2.

Table 4.2 T Test Results for Correlated Samples

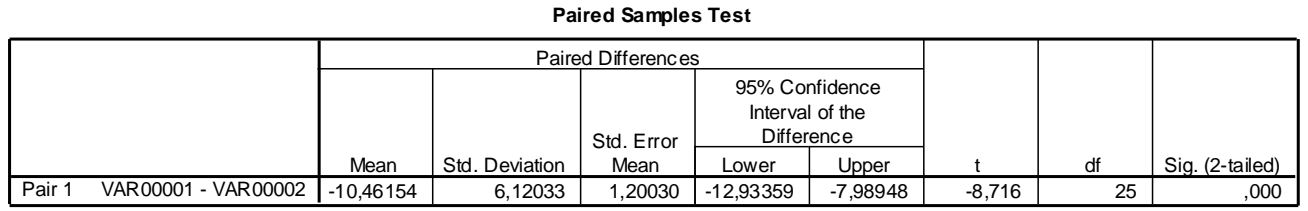

Based on the results of the $t$ test above, the significance of 0,000 is smaller than the determined significance of 0.05 , so that $\mathrm{H} 0$ is rejected and $\mathrm{H} 1$ is accepted. Thus it can be concluded that there are significant differences in the average pretest score and posttest score. This means that the application of Apoline in learning can enhance students' knowledge in Introduction to Philosophy course.

\section{Discussion}

The increasing in attitudes and students' learning outcomes can be explained as follows. First, there is an increase in attitudes related to the Apoline system which is developed using web-based information and communication technology. The Apoline system has a binding nature so students must be disciplined in carrying out tasks. If students are not disciplined, they will not be able to upload assignments because the Apoline system will automatically be closed. Another advantage is that the Apoline system can improve students' honesty because the tasks 
being uploaded cannot be plagiarism. By using a plagiarism detection application, students will not dare to commit fraud in making assignments. In the Apoline system there are also links or sites or specific learning resources that are related to specified tasks. If the link or learning source is clicked, there is an indication that students have curiosity. The more links or learning resources they access, it can be concluded that students have great curiosity. Second, an increase in learning outcomes related to the workmanship system and collection of tasks that have been determined on the Apoline system. The mechanisms are namely (1) students read the learning objectives well, (2) students read the material, (3) students work on individual and group assignments, (4) students upload the assignments, (5) feedback, (6) revise assignments, and (7) upload the revised task. This kind of mechanism will trigger students to continue learning and doing assignments regularly and upload them on time. In addition, in Apoline there are also a number of supporting materials and media to make it easier for students to understand the material so as to facilitate students in doing assignments.

\section{Conclusion}

Apoline has been developed using the moodle open source. Based on the assessment of design experts and assessment experts, Apoline is in a very good category while based on students' assessment, Apoline falls into good category. During the application of Apoline in learning, it turns out that it can improve the discipline, honesty and students' curiosity. Besides that, mastery of student knowledge also increases. Based on the results of this study, the development of electronic-based assessments is needed in the $21^{\text {st }}$ century.

\section{Reference}

[1] Aygün, Sibel \& Aydın, Selami. 2016. The use of e-portfolios in EFL writing: a review of literature. International Association of Research in Foreign Language Education and Applied Linguistics ELT Research Journal, 5(3), 205-217. http://dergipark. ulakbim.gov.tr/eltrj

[2] Birgin, O. \& Baki, A. 2007. The Use of Portfolio to Assess Student's Performance. Journal of Turkish Science Education. 4(2), 75-90. Avaliable at http://www.tused.org

[3] Garrett, N. 2011. An e-portfolio design supporting ownership, social learning, and ease of use. Educational Technology \& Society, 14 (1), 187-202. Avaliable at www.ifets.info/journals/14_1/17.pdf.

[4] Khales, Buad. 2016. Using Electronic Portfolio to Promote Professional Learning Community for Pre -Service Early Childhood Lecturers at AlQuds University. Journal of Education and Practice, 7(26). www.iiste.org

[5] Mustari, Mohamad. 2011. Nilai karakter: Refleksi untuk pendidikan karakter. Yogyakarta: LaksBang Pressindo.

[6] Zainul, A. 2001. Alternative Assesment. Jakarta: Universitas Terbuka. 